\title{
Metastatic renal cell carcinoma presenting as a cardiac tumour
}

\author{
Nisha Krishnakant Raiker, ${ }^{1}$ Erin Jensen, ${ }^{2}$ Bernadette Wodzinski, ${ }^{2}$ Kameswari Maganti $^{3}$
}

'Department of Internal Medicine, McGaw Medical Center of Northwestern University, Chicago, Illinois, USA ${ }^{2}$ Cardiac Sonography, McGaw Medical Center of Northwestern University, Chicago, IL, USA ${ }^{3}$ Department of Cardiology, McGaw Medical Center of Northwestern University, Chicago, Illinois, USA

\section{Correspondence to} Dr Nisha Krishnakant Raiker nisha.raiker@northwestern.edu

Accepted 10 November 2018

\section{DESCRIPTION}

A 58-year-old woman with no medical history presented to her primary care physician for an annual physical examination, reporting intermittent bilateral lower extremity swelling and an $18 \mathrm{~kg}$ weight loss over a 2-year period. A systolic cardiac murmur was noted on physical examination. A transthoracic echocardiogram was performed, demonstrating normal left ventricular size and systolic function, a $5 \times 4 \mathrm{~cm}$ well-circumscribed echodensity in the right atrium (RA), extending from the inferior vena cava (IVC) with associated severe tricuspid regurgitation (figure 1). Full laboratory evaluation was notable for elevated liver enzymes, prompting further evaluation with liver ultrasound with Doppler that detected a large IVC thrombus. CT of the chest, abdomen and pelvis was done to assess for underlying malignancy, which revealed a large renal cell mass with associated IVC tumour thrombus. The patient was started on therapeutic heparin and transferred to a tertiary care centre, where a multidisciplinary team assumed her care. MRI of the abdomen and pelvis further demonstrated a heterogeneous left renal mass measuring $13 \times 9 \times 17 \mathrm{~cm}$, abutting the aorta and encasing the left renal artery. The tumour was noted to extend through the IVC and into the RA, reaching the plane of the tricuspid valve with an intra-atrial component measuring $4.5 \times 4 \mathrm{~cm}$. Retrocrural and paraaortic lymphadenopathy along with left adrenal gland metastases were also noted (figure 2). Histological diagnosis was achieved by tissue biopsy of a right upper lobe lung nodule noted on chest CT, which revealed metastatic clear cell renal cell carcinoma. A multidisciplinary team considered possible radical nephrectomy, tumour embolectomy and cardiotomy for RA mass resection. Given her metastatic disease and the complexity of tumour burden,

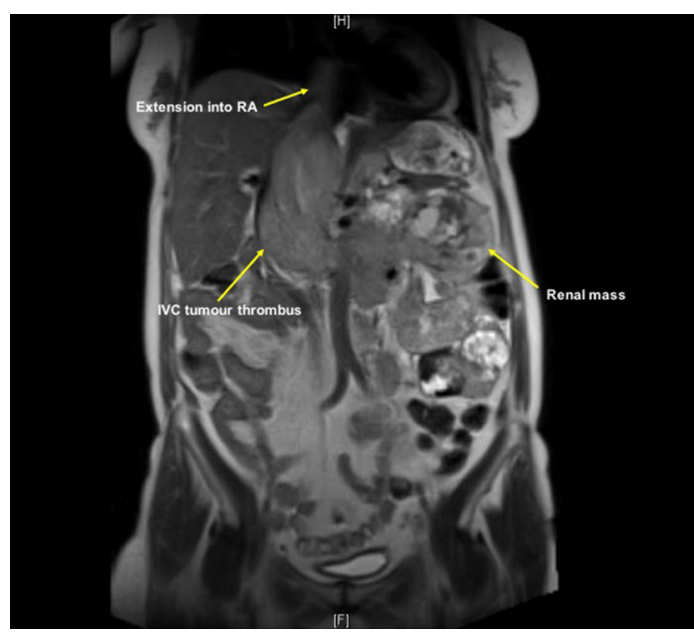

Figure 2 Coronal view of the MRI abdomen and pelvis shows a $12.9 \times 8.8 \times 16.6 \mathrm{~cm}$ heterogeneous mass with tumour thrombus extending into the inferior vena cava (IVC) and right atrium (RA).

she was deemed not to be a surgical candidate. The patient is now followed by medical oncology and receives palliative chemotherapy with pazopanib, a tyrosine-kinase inhibitor.

While primary cardiac tumours are rare, cardiac metastases represent up to $9 \%$ of intracardiac masses and are a result of direct extension, haematogenous or lymphatic spread. They may cause symptoms, but often are clinically silent and revealed only on autopsy. Echocardiography is the initial diagnostic tool of choice for detecting cardiac masses due to its wide availability, lack of radiation and diagnostic accuracy. Nevertheless, it can be limited by poor acoustic windows and an inability to visualise extracardiac structures. Additional imaging, such as cardiac MRI or chest CT, should be used
Check for updates

(C) BMJ Publishing Group Limited 2018. No commercial re-use. See rights and permissions. Published by BMJ.

To cite: Raiker NK, Jensen $E$, Wodzinski $\mathrm{B}$, et al. BMJ Case Rep 2018;11:e227336 doi:10.1136/bcr-2018227336

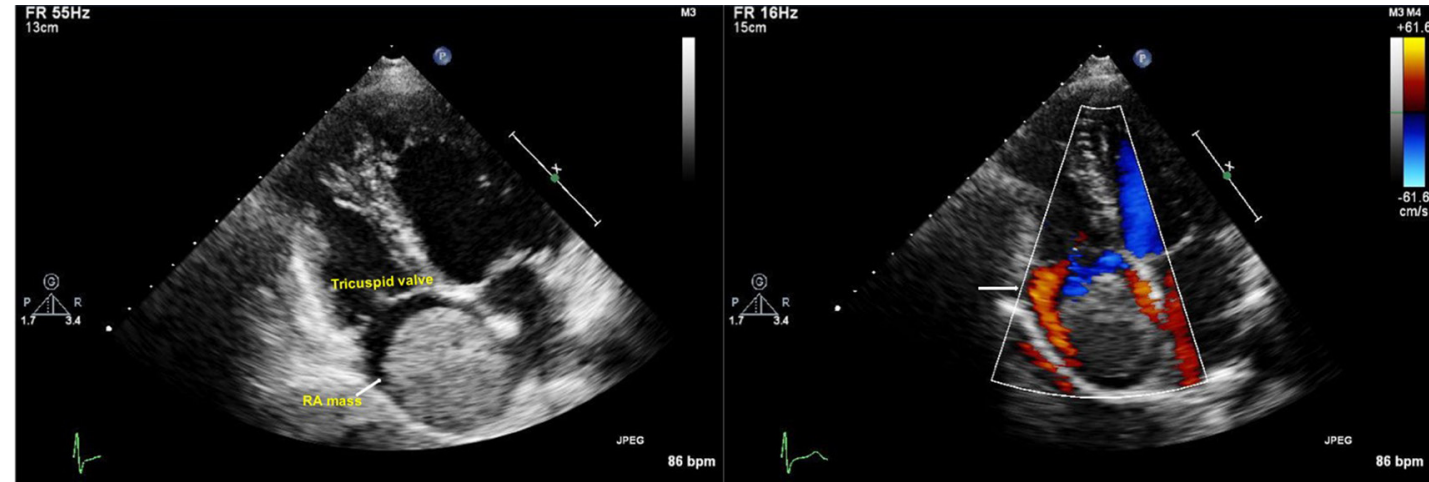

Figure 1 Right atrial mass $(5.2 \times 4.4 \mathrm{~cm})$ is noted on 2D echocardiography. Tricuspid regurgitation around the mass is noted on echocardiography with Doppler. RA, right atrium. 
to better characterise these lesions and determine their origin. Contrast-enhanced CT can distinguish tumour thrombus, which is characterised by contrast uptake and vascularity, from bland thrombus. Tissue biopsy should always be pursued for a histological diagnosis and to guide treatment. ${ }^{1}$ Cavoatrial involvement of renal cell carcinoma is an unusual presentation and surgical resection is challenging, resulting in high perioperative mortality and complication rates. ${ }^{2}$ Over the past decade, better understanding of molecular genetics have enabled us to provide

Learning points

While primary cardiac tumours are rare, cardiac metastases are a relatively common aetiology of intracardiac masses.

- Diagnosis of cardiac metastasis is often made by echocardiography, with MRI or CT aiding in the characterisation of extent and origin of disease.

- Cavoatrial involvement of renal cell carcinoma is an unusual presentation and surgical resection is challenging, resulting in high perioperative mortality and complication rates. targeted therapies for patients with renal cell carcinoma with or without metastatic spread.

Contributors NKR and KM provided substantial contributions to the conception, drafting and revisions for this work, and gave final approval for its submission and publication. EJ and BW provided the echocardiography images included in this work. NKR and KM accept full responsibility for all information provided in this work and all inquiries and concerns regarding its content will be addressed in a timely and professional manner.

Funding The authors have not declared a specific grant for this research from any funding agency in the public, commercial or not-for-profit sectors.

Competing interests None declared.

Patient consent Obtained.

Provenance and peer review Not commissioned; externally peer reviewed.

\section{REFERENCES}

1 Goldberg AD, Blankstein R, Padera RF. Tumors metastatic to the heart. Circulation 2013;128:1790-4.

2 Gaudino M, Lau C, Cammertoni F, et al. Surgical treatment of renal cell carcinoma with cavoatrial involvement: a systematic review of the literature. Ann Thorac Surg 2016;101:1213-21.

3 Lane BR, Rini BI, Novick AC, et al. Targeted molecular therapy for renal cell carcinoma. Urology 2007;69:3-10.

Copyright 2018 BMJ Publishing Group. All rights reserved. For permission to reuse any of this content visit

https://www.bmj.com/company/products-services/rights-and-licensing/permissions/

BMJ Case Report Fellows may re-use this article for personal use and teaching without any further permission.

Become a Fellow of BMJ Case Reports today and you can:

- Submit as many cases as you like

- Enjoy fast sympathetic peer review and rapid publication of accepted articles

- Access all the published articles

Re-use any of the published material for personal use and teaching without further permission

For information on Institutional Fellowships contact consortiasales@bmjgroup.com

Visit casereports.bmj.com for more articles like this and to become a Fellow 